\title{
The State's Selective Absence: Extractive Capitalism, Mining Juniors and Indigenous Interests in the Northern Territory
}

\author{
Sarah Holcombe
}

\section{Introduction}

Junior mining companies are an elusive group. They are by far the most numerically significant mining companies to operate globally, but most of them have a limited public profile and very few are publicly listed. Unlike the majority of major mining companies and some mid-tier companies, junior miners are unlikely to subscribe to international standards for corporate social responsibility (CSR), nor are they likely to have the internal resources and capability to demonstrate alignment with these standards. ${ }^{1}$ We know comparatively little about how junior miners engage with local and prior interests, especially those of Indigenous people.

1 International standards for the extractive industry include the International Finance Corporation (IFC) Performance Standards, and those that the International Council for Mining and Metals (ICMM) members endorse, which mirror the IFC standards. To gain membership of the ICMM, companies have to commit to establishing particular policies and procedures to ensure that they align with the standards. However, compliance measures to ensure implementation of these policies is a significant gap. 
For instance, do they simply follow the minimum regulatory standard for the jurisdiction and, if so, are these adequate for the task of ensuring that Indigenous peoples can access their rights and interests?

While there is no set definition for a junior mining company, 'juniors' may be defined by their size or by their role within the industry (e.g. as companies that discover and develop new resources to the point at which they can be taken over by larger operators). The latter appears to be a function of the decision by many of the 'senior' companies to cut back on exploration spending around the turn of the millennium. However, what matters for the purpose of this chapter is the way that juniors are defined by their entitlement to specific state subsidies; yet they typically underperform in terms of social and environmental responsibility compared to larger mining companies (Dougherty 2013: 3; Lyons et al. 2016). Noting, of course, the obvious caveat that major companies do not always meet their own CSR commitments.

This chapter will explore the case of one such company seeking to operate in the Northern Territory (NT) of Australia, which, for ethical reasons I will refer to as 'Top End Mining', as they are still seeking approval to develop a mine. I argue that a focus on junior miners provides an important (and largely overlooked) window into the strategic presence and absence of the state in resource extraction contexts, and helps to reveal the structural factors that shape the relationship between miners and Indigenous communities. In this chapter, I set out to achieve three things. In the first part of the chapter, I provide an overview of this particular mining project, and the key features of junior miners, addressing a gap in anthropology of mining literature (see Bainton 2020). I then consider the regulatory limitations within the environmental and social impact assessment processes in the NT, in comparison with other Australian jurisdictions, and the way that junior mining companies have been able to take advantage of this 'absence' to the detriment of Aboriginal communities in mine-affected areas. This provides the basis to consider the disconnection between this impact assessment process and the agreementmaking process for which provision is made under the Aboriginal Land Rights (Northern Territory) Act 1976 (Cth) and subsequent native title legislation. This disconnection is by no means unique to the NT; it is also found in other parts of Australia, and in Papua New Guinea.

The political context of the NT includes the regulatory frameworks at state and federal levels; local-level agreements between Indigenous groups, the mining company, Indigenous representative bodies; and, importantly, 
the structural inequality that frames this 'Top End' remote Indigenous region. The broader sociopolitical context is framed by the paradigm of extractive capitalism, exemplified by the Australian Government's White Paper on Developing Northern Australia (AFG 2015). This narrative draws on the language of developing the 'untapped promise [of], abundant resources', 'enabling infrastructure [for] agriculture, aquaculture and previously stranded energy and minerals resources' and 'making it easier to use natural assets' (2015:4-5). While there is a nod towards consulting with Indigenous interests, Indigenous people are regarded as another set of stakeholders rather than a distinct majority interest (in remote areas) in this development approach, which has been robustly critiqued (Morrison 2017; Chambers et al. 2018; Archer et al. 2019). ${ }^{2}$ Likewise, neither does this approach to Indigenous interests specifically recognise or focus on the distinct and unique cultural and social conditions of this Indigenous domain, as the mainstream or standard approach to permitting and approvals processes for extractive projects is transplanted to this context.

In this chapter I am especially concerned with the limitations of the current 'environmental impact assessment' (EIA) regulations and processes, which also include the requirements for undertaking an 'economic and social impact assessment' (ESIA) for new mining projects (NTG 2013). Conventional approaches to ESIA (and social impact assessment or SIA generally) are based on a 'no harm' approach, where the intention is to ensure that projects do not inflict additional harm upon local environments and communities. However, this raises critical questions about how conventional forms of ESIA can address existing socioeconomic disadvantage. This also draws attention to the relationship between the ESIA process and the agreements that are negotiated between the proponents and the Indigenous groups for mining projects. These regulations and processes concomitantly highlight the multiple ways in which the inherent deficiencies of junior mining companies are exacerbated in remote Indigenous contexts. The sociocultural elements of project impact, which are arguably the most complex, are demonstrably the least regulated. Yet, it is in this domain where Indigenous rights and interests are most at risk, and the possibilities for local forms of development are most pressing. In this context, the limitations of the usual 'no harm' approach to EIA for extractive capitalism become apparent.

2 In response to the criticism from Indigenous leaders based in the north, including Yu and Morrison, an Indigenous reference group was established in late 2017, which included these two leaders among the eight (Canavan and Scullion 2017). 
Tracing the key aspects of the regulatory context within which the Top End Mining company is seeking to operate sheds light more broadly on the political economy within which the extractive industries in general operate across this jurisdiction-for which, of course, there may be parallels in other jurisdictions. Likewise, I argue that the approach of this particular company to the task of seeking project approval is in some ways representative of other junior companies that are also operating, or have done so, in the NT. And, as will be elaborated, although the absence of the state is apparent in the channelling of particular models of extractive development on its remote Indigenous citizens, the state is present for these same citizens in other governance contexts (see also Lewis, Chapter 8, this volume). This sectoral dimension of the state's selective engagement is felt through the structural inequalities that mark out the daily lives of Indigenous Territorians in a diverse range of punitive governance and conditional social welfare measures, where the state is very present.

\section{Top End Mining: Reviving a 'Stranded Asset'}

Top End Mining is a subsidiary of a larger international company that has multiple business interests, including trading and vehicle distribution. This mining company was established through the purchase of existing mining leases, their associated 'stranded assets' and the existing exploration and mining agreements that had been negotiated between the previous company and the Northern Land Council (NLC), as the statutory representative body for Indigenous interests under the Aboriginal Land Rights Act (ALRA). The previous company, also a junior miner, had gone into voluntary administration. The stranded assets include a trial pit (where bulk sampling was undertaken by the previous company) in an open-cut operation, a laboratory and an accommodation village, both in the form of demountable buildings, for up to 60 staff. This trial pit remains in 'care and maintenance': there is a rotating skeleton staff of two on/two off, as it has not been producing since 2014 and operated for less than two years. The other mining leases and exploration licences do not have any infrastructure, while the total 'mine area disturbance footprint' is potentially around 2,400 hectares, according to the 'notice of intent' lodged for the environmental impact statement (EIS). 
As a result of the resuscitation of this mining project, the ESIA process did not start from scratch, so the company had effectively purchased a range of approvals. The existing local agreements had been moved across (or 'novated') to this new company at a meeting convened by the NLC for the company to discuss their proposal to reopen the mine and develop the other leases with the Traditional Owners (TOs), as customary land owners are termed under the ALRA. At that meeting, however, the additional aspects of the project, which subsequently required the ESIA processes, were not raised. Yet, as it unfolded, approval for the new aspects of the project were essential for its economic viability and, as will be discussed, the proponent appeared keen to ensure that the only approvals required for this additional stage were those of the state, rather than the TOs as well.

The agreements entail a range of company commitments, which include: cultural heritage protection, payment of mining royalties, and preferential employment for TOs as agreement beneficiaries. Likewise, if the project proceeds (and the new aspects gain the appropriate approvals) then, as part of the agreement, Top End Mining has to prepare and complete an ESIA and associated management plan with the input of TOs and the NLC. This second ESIA is in addition to that required by the regulatory regime, and the focus would be on Indigenous interests. This ESIA, including a baseline assessment, is not only essential for assessing the social impact of the operation over time, but, if done well, could also be a very useful tool for the region in negotiating their service delivery needs with government (see for instance Taylor et al. 2000; Taylor and Scambary 2005; Taylor 2018). ${ }^{3}$ Indeed, the possibility of being engaged in establishing such a baseline for the region was a catalyst for my involvement in this project through the Centre for Social Responsibility in Mining at the University of Queensland. As I will discuss below, I was engaged to prepare the section of the ESIA on 'culture and heritage' and, as an extension of this, the draft 'cultural heritage management plan' for the project. Hence, my growing recognition that the predominant focus

3 However, such an ESIA will require significant resourcing and good faith from the company, while the NLC will need to ensure that the research occurs. There is no evidence that the previous company - under the same agreement - undertook an ESIA. Furthermore, in remote areas especially, the methodology of Australian Bureau of Statistics (ABS) census collection has been strongly critiqued as not reflective of Indigenous households and patterns of mobility. Likewise, in some regions there is an acknowledged undercount by as much as 40 per cent. Such an undercount has direct implications for service delivery (Martin et al. 2002; Taylor 2018). 
of the regulatory system that I had to work through was to assess and manage for environmental impacts. Minimal state guidance was provided for the social impacts, which are embedded within the ESIA process.

As this mining company was specifically established to develop several mineral deposits, it is not surprising that they do not have existing 'social performance management systems' and staff in place. This term refers to the resources and capabilities that companies need in order to manage a broad range of socioeconomic and political issues, and risks, in the context of their operations (see Johnston and Kemp 2019). In this case, the entire company consists of two directors, one of whom lives internationally, a secretary and the four staff members responsible for the care and maintenance of the site-and as we shall see, this is more or less representative of many junior miners.

\section{The Precarity and Culture of Junior Miners}

There is no universal definition of a junior mining company and considerable debate surrounds the criteria that classify a company as a junior miner. Much of the critical literature (Dougherty 2011, 2013; Lyons et al. 2016) and the online financial guidance (Anon. 2019) focuses on junior gold miners. The boundaries between the different classifications of senior, mid-tier and junior firms are ambiguous, though they are usually categorised by their numbers of sites, levels of capitalisation and sources of revenue. According to Cranstoun, senior firms derive their revenue from production and sale, whereas juniors are essentially venture capital companies, while mid-tier firms derive capital from both equity financing and production and sale (quoted in Dougherty 2013: 343). Another definition also indicates that junior miners are neither producing companies nor the recipient of significant income from production or from some other business venture (Anon. n.d.a). These definitions do not fit the current case study, nor the neighbouring operation, which will also be briefly discussed, as they are both producing companies. This reinforces the fact that very little research seems to have been undertaken on junior companies, and that they are an extremely diverse bunch.

The Australia-based 'Junior Miners' website (www.juniorminers.com/ about.html), which began in 2007, lists over 2,000 junior miners globally. To gain perspective, this compares with the Minerals Council of 
Australia (MCA), which has 45 members, ${ }^{4}$ and the International Council on Mining and Metals (ICMM), which has 27. The largest transnational companies, or the 'majors', and some aspirational mid-tier companies seek membership of these peak professional bodies. While these majors also extract the bulk of the earth's minerals, there has been a proliferation of junior companies globally (Dougherty 2011). One reason cited for this proliferation has been the rent-seeking behaviour of juniors, as incentivised by the state (Dougherty 2013), as well as the recent uptick in the mining industry.

Similar to Canada (see Dougherty 2013: 341), the Australian state incentivises the formation and proliferation of juniors, as it does more generally the mineral and fossil fuel industries. A 2017 federal government scheme involved 'tax incentives for junior exploration companies to encourage investment and risk taking' (Turnbull 2017). This entailed a government commitment of AUD100 million to secure additional private investment, referred to as the Junior Mineral Exploration Tax Credit. ${ }^{5}$ Likewise, on a significantly larger scale, the industry more generally receives significant support. According to Peel et al. (2014), over a six-year period, Australian state and territory governments spent AUD17.6 billion supporting the mineral and fossil fuel industries. Of this total, between 2008 and 2015, the NT Government spent almost AUD407 million on minerals and fossil fuel expenditures and concessions. Ironically, given the deficit position of the NT budget, in 2013-14, of the AUD113 million in mining royalties received, AUD88 million was returned in assistance to the minerals and fossil fuel industries (Peel et al. 2014: 4-12). Powerful industry lobby groups, including the MCA and the Association of Mining and Exploration Companies (AMEC) are active in pursuing these cost savings on behalf of industry. ${ }^{6}$

4 It also has approximately 15 'associate members' who are not mining companies but consultancy firms.

5 The Junior Mineral Exploration Tax Credit is said to be an improvement on previous pilot programs assisting junior mineral explorers and has been developed based on industry feedback. Offering incentives for investment is of course not limited to junior mining companies. Glencore, which owns the MacArthur River mine in the NT, is known to pay zero royalties in most years. The only known royalty payment, of AUD13 million, came in 2008 after a historic peak in the zinc price. At best the mine would contribute just one third of 1 per cent of NT Government revenue (Campbell et al. 2017).

6 According to AMEC's 2019 annual report, they have 'saved the industry millions of dollars by being willing to challenge public policy issues and advocate crucial initiatives to reduce the cost of doing business for the industry ... AMEC has ready access to ministers, leading politicians and government decision makers in territory, state and federal levels' (AMEC 2019: 5). 
The absence of the state therefore manifests as a fiscal absence, reflected in the failure to claim taxes from the industry at both territory and federal levels. The NT is the only jurisdiction in Australia with a profitbased royalty system and because many extractive industry operations are capital and infrastructure-intensive, this often means that no royalties are paid at all by industry. This approach also assumes that any infrastructure and development the industry builds will have flow-on and broader benefits to communities and the region, in a 'trickle-down effect', both during and beyond life-of-mine.

Although some junior companies may subscribe to particular industry standards or may have developed their own policies, online 'networks' seem to be a major forum for information and discussion. ${ }^{7}$ These online services, some of which are fee-based (for subscriptions to magazines such as Junior Mining Monthly), provide insight into the attitudes and approach of juniors. ${ }^{8}$ Delving into several of these online sites is a window into the capital logic and cultural drivers that underpin the junior mining entrepreneur. An American investment site called the 'Outsider Club' (that also publishes the Junior Mining Monthly and the Junior Mining Trader), which runs the byline 'because you'll never be on the inside', speaks to an idealised frontier spirit that resists regulation and state oversight. As they state on their website: '[W] e'll ... help you shield your civil liberties and freedoms. We pledge allegiance to no political party. The Outsider Club will inform you of suspicious laws and policy-and show you how to stand up to and fight against them' (Outsider Club n.d.).

Perhaps unsurprisingly, the editors of this site are six white American men, suggesting that the 'outsiders' as a frame of reference is a limited reference point. The business logic of junior miners is framed around risks and uncertainty. As the Australian junior mining online page states: 'those uncertainties and risks can range from everything from government politics to commodity prices and everything in between' (Anon. n.d.b). Though such risks are not unique to junior companies, they are typically very reactive to the volatility of the global minerals market and can disappear just as fast as the mineral stocks plummet. This is one reason

7 See for instance: www.juniorminingnetwork.com. Note that mid-tier and major companies also engage in networks and forums.

8 Note, however, that there are blurry and shifting boundaries between these 'categories'. For instance the Australian company Newcrest is listed as a junior on the 'Junior mining' site, but according to its website it is one of the largest gold mining companies in the world and it is also a member of the MCA and the newest member of the ICMM. 
why it is commonplace for mines operated by junior companies to become abandoned or placed in 'care and maintenance' until another company picks up the operation. This was the case of the 'stranded asset' purchased by the Top End Mining company. Likewise, during the same period another neighbouring mine, and its associated stranded assets, were also purchased by another junior company. ${ }^{9}$

The parent company that established Top End Mining is not readily searchable online and no information could be located about their corporate business standards. Of note however, is that mining does not seem to be a significant element of their diversified business. Since incorporating, however, and during the process of applying for the EIS approvals (still ongoing as I write), Top End Mining has developed a onepage 'Sustainable Development Policy' (available online as an appendix in their Mining Management Plan). Their priority is clear in the first line: 'A fundamental objective of [the company] is to create long-term value for its owners through the discovery, development and delivery to its customers of mineral and related products'. ${ }^{10}$ The model of sustainability at play here is thus of the corporate financial kind. I am not suggesting that there is anything exceptional about the fact that these companies do not have social performance standards in place or have not employed the rhetoric of corporate social responsibility (CSR). However, the significant chasm between the approach to CSR of such companies and those of major companies and many mid-tier companies is of particular note.

Major companies, including those who are members of the ICMM, and some who are members of the MCA, generally have 'social performance management systems'. This term refers to the suite of integrated policies, procedures and guidelines that assist the company to manage the social dimensions and impacts of their operations. ${ }^{11}$ I suggest that we need to recognise that a major feature of junior mining companies is a consistent lack of CSR standards and associated governance systems. As Margaret Lyons and her co-authors note: 'little is known about the meaning and practice of CSR in junior and mid-tier companies' (Lyons et al. 2016:

9 According to one often cited estimation, there are approximately 50,000 abandoned mines in Australia - from major open-cut mines to small mine shafts. No major open-cut mine has been fully rehabilitated and relinquished in Australia (Roche and Judd 2016).

10 Note, that in the interests of not identifying this company I will not provide a reference for this.

11 These typically include policies, guidelines and standards that cover: 'communities', 'stakeholder relationship management', 'human rights', 'Indigenous peoples', 'local procurement and employment', 'social baseline and impact assessment', and 'local and community grievance' mechanisms. 
204). Though there has been a significant global push to develop such standards across most corporate sectors, juniors seem to have missed this trend and largely continue to fly under the radar. As observed by a staff member of a major mining company:

a lot of the juniors ... think community engagement is just a kind of luxury or add on [because] it costs money ... and they just want to get on with digging ore out of the ground ... the digging the hole bit is easy, its what's outside the mine fence and engaging successfully there that's the key to business going forward. (in Doyle and Carińo 2013: 48)

In other words, for junior miners, the 'social' is an externality, far removed from core business, ${ }^{12}$ whereas more mature companies tend to consider the risk profile of new purchases and conduct their due diligence to understand what legacies they might be buying into. As a result, the ability of a junior company to sell the project to a larger development partner, once the project has gained the relevant approvals and established viability, can prove hazardous. The risk is that a development can be worthless if the project is encumbered by negative social and environmental legacies; a point also made by one particular mining major when it considers purchases (Doyle and Cariño 2013).

Nevertheless, even though major companies may have systems and standards in place, these are inconsistently developed and applied. As a result, many of the criticisms directed at juniors also hold for some midtiers and major companies. And, likewise, I readily acknowledge that there is a performative element to both the implementation of voluntary and mandatory industry standards, and public reporting (Fonseca 2010; Boiral 2013). While recognising these caveats and limitations, communities stand a stronger chance of gaining better social, economic and environmental outcomes with a company that has some social performance systems in place (and associated resourcing), and a reputation to protect, than a company that does not. Against this background to the operating logic of junior mining companies, I will trace the context within which this company, and the industry, operates in the NT.

12 See also Kemp and Owen (2013) who discuss this concept of 'core and non-core' for social performance in mining, noting that 'community relations is core to business, but not "core business"'. I suggest that this issue is significantly more pronounced for junior miners. 


\section{The Political Economy of the NT and Indigenous Social Development}

Unlike the Pilbara or Goldfields regions in Western Australia (WA) that are known as 'mining regions', and that effectively underpin that state's economy, the NT does not have a comparable regional or big infrastructure economy. ${ }^{13}$ Though mining is one of the three dominant industries in the NT, contributing 12.9 per cent of gross state product in 2019, the largest 'industry' is 'government and community services' at 23 per cent of gross state product, followed by service industries (which includes tourism) at 19.4 per cent (NTG 2020). This sector comprises public administration and safety, education and training, healthcare and social assistance. This most significant sector is also predominantly funded by the Commonwealth Government, to the effect that approximately 80 per cent of the NT's income is funded federally (see Zillman 2018). One reason the NT receives such a significant proportion of commonwealth funding is primarily because of its large Indigenous population.

Approximately 30 per cent of the total population of the NT is Indigenous and it is recognised that on the major indicators-education, health, housing and employment-they experience high levels of disadvantage, relative to the mainstream population. More than 70 per cent of this total Indigenous population live in remote or very remote areas with significant historical deficits in civil society organisations (such as not-for-profits, educational and advocacy bodies) and public infrastructure. Although a significant proportion of this Commonwealth grant is funding for Indigenous Territorians, because the money is calculated by accounting for Indigenous disadvantage and remote servicing, only about 50 per cent of the allocation is actually spent on them. ${ }^{14}$

The mendicant position of the NT Government is raised here as it has implications for their engagement with proponents of large-scale infrastructure projects, including mining. And it is in tension with the fact that the NT is one of the few jurisdictions globally with legislation recognising collective Indigenous rights to land that includes rights to

13 Mining makes up 36 per cent of gross state product in WA (WASG 2020).

14 This is because there are 'no strings attached' to the money when it leaves Canberra and flows into the NT Government's accounts. This issue has been a major and ongoing source of contention and debate in the NT, and between the NT and the Commonwealth governments, notably for Indigenous parliamentarians and Indigenous representative bodies (Davidson 2018; Walsh 2018). 
free prior and informed consent (FPIC) over development on this land and inalienable freehold title. ${ }^{15}$ More than 50 per cent of the NT is now recognised as Aboriginal Freehold Title, under the ALRA, while much of the remaining land is subject to native title rights and interests, including 85 per cent of the coastline. The Native Title Act 1993 (Cth), which applies to the whole of Australia, is a poor cousin to the ALRA. Native title is the recognition that Aboriginal and Torres Strait Islander people have rights and interests to land and waters according to their traditional law and customs, as set out in Australian law. However, it comes in two forms: non-exclusive possession and exclusive possession. ${ }^{16}$ The vast majority of native title recognised Australia-wide is non-exclusive and only offers the right to negotiate, not the right of veto or to protect places of significance (McGrath 2016). However, in the NT there have been significant cases where exclusive possession has been recognised, including Blue Mud Bay No. 2 (AIATSIS 2016).

While this land tenure in the NT would appear to provide Indigenous landowners with a powerful and strategic political position, the regulatory and governance environment diminishes these rights at both territory and federal levels. A significant mechanism leading to marginalisation of Indigenous interests in land occurs principally through the state (Territory) level EIA process (which encompasses ESIA). This is triggered when a proponent submits a 'notice of intent' to develop a projectincluding mining operations. The NT Government Environmental Protection Authority then provides terms of reference for the preparation of an EIS for the specific project.

In the case discussed here, and similar to other projects, this requires the proponent to identify all of the processes and activities associated with the project and the ways in which they will mitigate and monitor

15 The ALRA is Commonwealth (federal government) legislation. The right to FPIC is a qualified one, however, as a 'yes' to exploration is also a 'yes' to mining. While a 'no' to exploration is only for 5 years, when the company can return to ask again. There have been some strong campaigns by TOs that 'no means no'; that the company is not welcome to return. Of note, other states globally that have legislated Indigenous peoples' land rights, including the right to FPIC, are the Philippines (with the Indigenous Peoples Rights Act of 1997) and some Latin American states that are signatories to ILO Convention 169 (which recognises Indigenous and Tribal Rights) and that have adopted domestic laws to implement the Convention, including Colombia, Chile, Brazil and Peru.

16 In the case of non-exclusive possession, native title is found to coexist with non-Indigenous property rights such as pastoral stations or areas where there is a shared interest with another party (being the most common form). Exclusive possession native title includes the right to possess and occupy an area to the exclusion of all others. Exclusive possession native title can only be granted across certain areas such as unallocated crown land or areas that were previously held or owned by Aboriginal people, which was found to be the case for the Blue Mud Bay native title claim in Arnhem Land. 
environmental and social impacts, as well as outlining the proposed potential economic and social benefits. Because the reporting requirements are so specific, the proponent typically engages a consultancy firm, who then engages experts to prepare sections for the EIS addressing particular areas that require impact assessment, such as hydrology and the biological and physical environment. In the NT context, archaeological experts are routinely engaged to address the tangible cultural and historical aspects of the project, but it is less standard for other social scientists, such as social anthropologists, to be engaged in the cultural and social aspects of the impact assessment.

The Top End Mining company has to deal with a challenging sociopolitical context of poor mining legacies in the region from previous juniors, including abandoned mines and associated agreements, complex land tenure arrangements and customary governance structures. These land tenures include Aboriginal Land (both granted and not yet finalised), native title, pastoral lease, national park, marine reserve and a special purpose lease. All of these formal land tenures are underlain by customary land tenures, which, in the case of Aboriginal Land, intersect. The rest of this section begins to outline the social and political context within which this company is seeking to operate and the existing vulnerabilities for the Aboriginal population.

As a very remote area in the NT, the region where the company is seeking to operate is an Aboriginal domain. The population, the languages and the social structures are Aboriginal, while the formal land tenure is Aboriginal land, recognised as native title land or under native title claim. More specifically, in this local government area, as one of five in the regional shire, 80 per cent of the population identify as Indigenous. ${ }^{17}$ Only 30 per cent speak English at home, with nearly 50 per cent of the population speaking Kriol and 15 per cent local and other languages. In administrative terms, this region is part of a regional shire with a total population of 7,500 people over a geographic area that covers 186,000 square kilometres. ${ }^{18}$ This regional shire includes nine Aboriginal communities, many more outstations (small family-focused homelands) and four towns, which are mostly populated by non-Aboriginal people.

\footnotetext{
17 To avoid identifying the proponent, I do not name this region.

18 Key industries in the region are pastoralism, some agriculture, extractive industries, and tourism and government services. The Council is one of the largest employers in the region. Like all the other remote areas of the NT, this shire is dependent on public sector grants and funding, having only a low rates base from which to derive income for municipal services (via privately owned houses/private property).
} 
According to the 2016 census, the average annual income in this region is AUD23,500. ${ }^{19}$ This average income is low, reflecting the fact that almost half of the population is unemployed. The basic Newstart (government unemployment) allowance is just under AUD15,000 per year, which is less than half of the national minimum wage. A majority of people living in households whose reference person receives a social security benefit fall below the poverty line, according to the Australian Council of Social Services (Davidson et al. 2018). ${ }^{20}$ Other barriers to mainstream forms of development are also high rates of substance abuse and the use of violence as a form of social regulation. ${ }^{21}$

This demographic profile is indicative of a vulnerable and marginal population. The regional education profile also suggests limited employment, as only 7.6 per cent of the population have completed year 12 , while the most substantial cohort, at 21.1 per cent, have completed year 9 or below. ${ }^{22}$ The region is also very young demographically, with a median age of 24 years, while 31.5 per cent of the total population is under 15 years of age. Aboriginal people over the age of 65 make up less than 5 per cent of the population.

This set of structural factors clearly requires an innovative approach, not only to forms of development, but also to the ESIAs that are required as part of the EIA process before developments proceed—and, if developments do proceed, to the ongoing role of the company in supporting said forms of development. Yet, with few other mainstream economic opportunities in remote communities, there has been growing pressure and a normative assumption by the state (in this case the NT Government) that mining is a preferred development path. The recent government approvals for non-conventional gas fracking to proceed is also indicative of this approach (Chlanda 2017; NTG 2018a; see also Espig, Chapter 6, this volume). ${ }^{23}$

19 See Martin et al. (2002) for a critical engagement with the appropriateness of the ABS census method for remote and very remote populations.

20 Housing tenure also has a major impact on poverty. The majority of people below the poverty line are also renting, another characteristic of this regional Aboriginal population (Davidson et al. 2018), where there are very few home owners. Note that there are no incentives to own your own home (hence take on a mortgage), as the market economy barely exists in remote communities (Altman et al. 2005). 21 In 2005-06 the rate of alcohol-attributable deaths in the NT among non-Aboriginal people was double the national rate and, among Aboriginal Territorians, 9 to 10 times the national rate (D'Abbs 2017).

22 These unemployment rates and the education profile is comparable to other remote shires in the Northern Territory.

23 Fracking has been banned in Victoria and there are moratoriums in place in NSW and WA. In NSW there have also been buybacks and cancellations of exploration licences (Cox 2018). 
This extractive capitalist approach to development has been reinforced by the diminishment of the welfare or social state, so that market-driven development has begun to present the dominant option for Aboriginal people. Likewise, access to social security is increasingly conditional via various 'work for the dole schemes'. The abolition of the Community Development Employment Program in 2015 was part of a broader policy approach enforcing the mutual responsibility paradigm as an element in citizenship entailments. The Community Development Employment Program was purpose-built for remote Indigenous contexts and provided flexible adaptive forms of employment. Its replacement with the Community Development program, in which people effectively do the same work but are classed as unemployed and now under the surveillance of the social security system, was perhaps one of the most obvious shifts towards a punitive order of federal state governance (see Kral 2017; Sanders 2017).

Though extractive capitalism is often acknowledged as intensifying neoliberal pressures, for instance in mining regions such as the Pilbara (Peck 2013; Taylor 2018), it has been also promoted by some as the panacea for the socioeconomic issues of remote Indigenous communities (Langton 2013, 2017). Marcia Langton has argued that post the Native Title Act, and the subsequent wave of negotiated agreements and improvements in the culture of mining companies, the extractive industry generates local benefits that exceed local costs (Langton 2013). Within Australia and Canada, as settler colonies, there has also been consideration that the retreat of the state has created space for Indigenous people to exercise their agency (for instance, Slowey 2008; Feit 2010), notably in relation to negotiating agreements for resource development (Langton et al. 2003; O'Faircheallaigh 2011). The state is rarely a party to these agreements and, as will be discussed, they usually contain a complex mix of training, employment and community development initiatives.

Like Canada, Australia does not have '[a] public policy framework that guides [agreements] negotiation, terms of reference or implementation' (Cameron and Leviton 2014: 26). Although mining land use agreements can potentially be positive for the beneficiaries, any benefits hinge on their successful implementation. This includes the capacity of the company, the Aboriginal communities and the Indigenous representative body to uphold the conditions of the agreements. Given the significant level of disadvantage that requires addressing and, thus, what these agreements are expected to achieve, this lack of public policy is both surprising and a major gap. 


\section{A Selectively Present State}

As I have begun to outline, in the NT, the absence or retreat of the state has been selective. On the one hand, the state has never been present in relation to the many negotiated agreements between its Aboriginal citizens and mining interests, ${ }^{24}$ while we have seen a retreat of social welfare, such as the Community Development Employment Program and a mainstreaming of Indigenous services such as housing. On the other hand, we have seen an increase in the presence of the state in forms of punitive governance and surveillance, and a coupling of responsibilities and duties with citizenship entitlements (Holcombe 2018; Spiers Williams 2019). While Shared Responsibility Agreements, which were introduced by the conservative Howard government and tied welfare entitlements with discretionary development funding, have fallen out of the policy toolbox, the 'policy settings' of shared responsibility have continued (Sullivan 2011: 33), as can be seen in the 2015 NT Homelands Policy: A Shared Responsibility. Memoranda of understanding (MOU) have also become commonplace, such as the community safety MOU between local communities, their regional shire and the local police service in relation to community safety issues. This attachment of responsibilities and duties to (Aboriginal) citizenship entitlements is now an intrinsic element of public services and policies.

The NT Emergency Response of 2007 was a clear marker of this restructuring of Aboriginal citizen/state relations. ${ }^{25}$ Since 2007, various legal reforms have specifically targeted Aboriginal citizens in a selective increase in state interventions. These include mandatory sentencing and mandatory reporting laws in relation to domestic and family violence issues, leading directly to an escalation of male and female Aboriginal incarceration rates and the removal of 'at risk' children. The result is that Aboriginal people now make up approximately 85 per cent of the NT prison population (NTG 2018b), while there was also a threefold rise in child removals since 2007 (Gibson 2015). Other punitive laws

24 As far as I am aware, one of the very few negotiated mining land use agreements in Australia where the state is also a party is the Century Agreement in Queensland (see Everingham et al., Chapter 9, this volume).

25 The Northern Territory Emergency Response was triggered by widespread allegations of child sexual abuse within Aboriginal communities. A raft of extreme measures were implemented that, taken together, constituted a governmental intervention unmatched by any other policy declaration in Indigenous affairs in the last 40 years (see Altman and Hinkson 2007). 
criminalise an increasing range of Aboriginal behaviours with a focus on 'public' offences, such as alcohol consumption and driving infringements. As most small communities now have police stations, post 2007, the risk of over-policing is routine (Pilkington 2009; Pyne 2012). This punitive governance is an element in the state's attempt at coercing a particular type of disciplinary civility (Hindess 2002; Holcombe 2018).

This active state presence in very particular areas of Aboriginal policy, programming and legislation, conversely brings into relief the state's absence in other areas of legislation for these same peoples. This absence is in relation to the Environmental Assessment Act 1982 (NT), which establishes administrative procedures to address development interests across the NT that also affect the Aboriginal estate and Aboriginal rights and interests. This Act stipulates the range of procedures a developer will need to address in an EIS for a project.

\section{How the State Minimises Indigenous Interests through the EIA Processes}

As discussed, the NT is predominantly comprised of Aboriginal-owned land under the ALRA. Significant portions of the remaining areas are either recognised as native title, or under native title claim. Yet, the interests of these Aboriginal landowners and managers are barely visible in the EIA processes for development on these lands-especially in the extractive industries.

The predominant focus of the EIA process is to assess and manage for environmental impacts. Minimal guidance is provided for the social impacts that are embedded within the EIA process. The NT 'Guidelines for Preparation of an Economic and Social Impact Assessment' are six pages long (NTG 2013). ${ }^{26}$ This compares with the Queensland SIA Guidelines at 24 pages (QSG 2018) and the New South Wales (NSW) SIA Guidelines at 55 pages (NSWSG 2017). The NSW SIA Guidelines are also specific to the extractive industries, and the NSW Government has developed a comprehensive 'Guide to Community and Stakeholder Engagement', as part of their Draft Environmental Impact Assessment

26 They guide the proponent in their collation of the range of data that needs to be provided to government and the public about the potential economic and social 'contributions' and the impacts and benefits of the project. 
Guidance Series, as well as a 'Scoping Tool'. By way of comparison, in the EIS Terms of Reference for this particular project, while there was reference for the need to establish a 'stakeholder communication strategy', there was no guidance offered as to how to develop this strategy.

For TOs, the interdependence between the environment, customary law, governance and identity makes separating out the social impacts from the environmental impacts neither meaningful nor possible. Though as previously indicated, Aboriginal people own more than half of the NT and there are statutory requirements that underpin the ALRA, as well as other applicable acts, including the Commonwealth Native Title Act of 1993 and the NT Aboriginal Sacred Sites Act of 1989, the NT ESIA guidelines barely mention Indigenous peoples' interests. Rather, they state that 'consultation with Indigenous peoples has particular needs [sic]' and point practitioners to an obscure reference from the United States (NTG 2013: 4).

This obscure reference to a three-page document as a generic piece on 'Indigenous peoples', rather than the specific context of the NT, exemplifies the disconnection from the reality that Aboriginal people have significant interests under law for much of this jurisdiction, while most of the major mines are also on these lands. Aboriginal people are the major stakeholder. Yet, this lack of recognition and regulatory guidance diminishes these rights and interests. Whether this is the result of ignorance of what good guidelines look like, or yet another form of 'administrative violence' (Lea et al. 2018) to marginalise Aboriginal interests, or perhaps a combination of both, results in the same effect. As this legislation does little to accommodate the particularities of Aboriginal interests, so it becomes a form of absence.

In some ways, the minimal guidance (and thus expectation) from the NT Government can be addressed for each specific project, as the proponent's 'notice of intent' to develop the project then triggers a more detailed Terms of Reference (ToR) for the preparation of the specific EIS. However, in this particular project, only 3.5 pages of the 36 pages of the ToR for this EIS were allocated to how the 'cultural and historic' issues and the 'socioeconomic environment' should be addressed. A list of 'suggestions that may assist with highlighting the social and economic value of the project' was provided. Thus, when it comes to working with a junior mining company that is compliance-driven, pushing for higher standards was, I realised, a challenge. This became clear when I was discussing the 
draft SIA scope of works with the company. As the company preferred to maintain minimum compliance, rather than going beyond compliance, we discontinued this element of the project, and it was subsequently taken up by a consultancy firm. As will be discussed, while major mining companies may well have similar compliance-driven approaches to permitting, it did seem to me at the time that I was operating in not only a regulatory void, but also a void of corporate social standards. There were no other internal policy levers that we could lean on to direct the company towards more responsible practices.

I had initially only been engaged to prepare the section of the EIS which became the public documents for comment on 'Culture and Heritage' and the draft 'Cultural Heritage Management Plan'. The consultancy firm managing the entire EIS process had requested that I submit a scope of works for the SIA (excluding the economic component) and had also actively encouraged me to draw on the stronger practice standards of NSW, for instance. Among other issues, I had proposed to develop a 'Community and Stakeholder Engagement Plan' to augment the 'stakeholder communications strategy' that was required for the ESIA as part of the EIA process. This engagement plan was proposed as a resource that, though driven initially by the EIA, also looked post-EIA and would be reviewed as part of the project life cycle, rather than an exercise focused on ensuring the company would get 'over the line' in community approvals. It seemed especially important that this company develop an engagement plan, given they did not have any community engagement processes in place. That Indigenous interests are externalities to the business of ensuring that the project proceeds seemed to be facilitated by the NT Government during the EIA processes.

\section{Social Impact Assessment and Shifting the Baseline}

In industrialised countries, such as Australia, the standard approach to social impact assessment is to document the existing socioeconomic conditions within which a proposed development is to occur, assess its likely impacts and identify strategies to minimise and mitigate these negative effects (O'Faircheallaigh 2011). This baseline is then used to evaluate ongoing impacts from the project. However, there is an emerging approach to SIA that is critical of this method-especially when it is applied 
in regions with high levels of social vulnerability such as the NT. While the lack of attention to pre-existing negative impacts may be acceptable in some mainstream SIA contexts (such as regional or rural areas in Australia with a predominantly Anglo population), maintaining the status quo in contexts of marginality and vulnerability is not good enough. Applying a 'no harm' approach in this context renders invisible the particularities of local Aboriginal needs and interests. As Ciaran O'Faircheallaigh indicates:

existing [Aboriginal] social conditions are not simply a baseline against which subsequent changes caused by development are measured and deemed positive or negative. Rather they constitute a fundamental problem, and both social impact assessment (SIA) itself and the proposed development that is being assessed are judged in terms of their potential to change existing social realities. (2011: 138)

Attempting to carve out an approach that moves beyond mitigation and trade-offs recognises that the political ecology of extractive capitalism in the NT is currently limited to the two-sided conflict of economy versus environment (Escobar 2008). The state has been absent in recognising and facilitating alternative modes of production that celebrate or at least promote Indigenous interests, strengths and existing capabilities (see Altman and Kerins 2012; Chambers et al. 2018). There has been considerable critical analysis of the limitations of large-scale natural resource development, including mining, to fundamentally shift the well-being of the Indigenous peoples on whose lands mining operates (e.g. Trigger 1997; Langton and Mazel 2008; Altman and Martin 2009). However, these academic critiques (many of which focus on the NT) do not seem to have influenced NT resources policy, including EIA processes. There have, however been attempts over the last decade, co-funded by the federal government, to consider what a cultural and conservation economy could look like for northern Australia (Hill et al. 2008). Nevertheless, the only element of this approach to establishing sustainable forms of livelihood that has been actively supported by government are Indigenous ranger programs, which have been very successful and of which there are several in this region (AFG 2015; Mackie and Meacheam 2016).

An important feature of O'Faircheallaigh's 2011 case study mentioned above (of an SIA undertaken for James Price Point in the Kimberley region of WA) was that while the proponent (Woodside) funded it, it was produced as part of an independent process. The goals of the SIA were driven by Indigenous interests and managed by the regional representative 
body, the Kimberley Land Council. As he noted, in this context 'SIA is inextricably bound up with achieving basic change in underlying social conditions; that is with social development [and] ... sustainability' (O'Faircheallaigh 2011: 139). Such an approach actively manages for the inadequacies of conventional SIAs and ensures that the process is useful for those most impacted. This is markedly distinct from the majority of SIAs that are undertaken as a state-initiated element of a development project's permitting and compliance, which often lead to them being perceived as compromised - as they are funded by the proponent, specifically because they seek development approval. Likewise, Anthony Hodge, focusing on the extractives, uses a framework he terms 'contribution analysis' (Hodge 2018). He argues that a conceptual shift from the 'current deeply entrenched practice of focusing on the identification and mitigation of negative impacts (or effects) to a "higher test" based on the achievement (or not) of a net positive contribution to human and ecosystem wellbeing over the long term' needs to occur (Hodge 2018: 370; see also Bebbington and Humphreys Bebbington 2018).

Other relevant approaches to SIA, for this remote Indigenous context, include a human rights-based approach that draws on the core values of human rights as the framework (MacNaughton and Hunt 2011). Deanna Kemp and Frank Vanclay (2013) argue that in some contexts it is more effective to integrate human rights impact assessment with the social impact assessment process, rather than have them as stand-alone assessments. The linking of business and human rights initially emerged in response to a series of egregious cases of human rights abuses by business entities driven by market-based notions of access and entitlement to resources (for some notable cases see Kemp and Vanclay 2013). The mounting international pressure subsequently led the UN to establish the 'Protect, Respect and Remedy Framework' (Ruggie 2008) to promote business-related engagement with human rights, followed by the UN Guiding Principles on Business and Human Rights to 'operationalise' the framework (Ruggie 2011). Though I am not aware of any human rights impact assessment being undertaken in Australia, one was recently undertaken for the first time in Papua New Guinea for an SIA for a proposed liquefied natural gas project (Götzman and Bainton 2019).

Indigenous-led SIA, contribution analysis and human rights impact assessment highlight the limitations of applying the usual 'no harm' approach in the context of a low socioeconomic baseline and challenging social conditions. This is further compounded by a political context that 
actively marginalises Indigenous interests. Clearly, if the aim is only to mitigate in order to maintain this baseline, then the opportunity for mining to contribute or intervene in positive ways into these socioeconomic contexts is severely compromised. In this context, both the capacity and the attitude of the mining company is crucial, because if the company does not have capacity and positive intent then the SIA will be further compromised.

\section{Choices in a Context of Limitation}

Though the statistics of high unemployment and limited formal education do not define individuals, they do provide an indicator of the ways in which the parameters for agency and choice are established. This concept of 'agency' has gained popular currency in the development literature where it is sometimes defined as 'empowerment' and articulated through the related concept of 'voice'. ${ }^{27}$ As a 'process freedom', the ability to exercise agency is now accepted as part of mainstream development thinking (World Bank 2014: 6). In this context, limited mainstream education and work experience in a market economy act as constraining elements to engaging on equal terms with the proponent, even as mediated by the NLC. The options and limits for TOs, as social actors, are also mediated by the interrelation between an individual's subjectivity as a person and the subsequent agency they are able to manifest in any given context. As cultural responsibilities and obligations assert a determining role in what sort of 'agent' an individual can be, these cultural parameters need to be taken into account, as well as the structural effects of material poverty.

Against this backdrop of apparent material need, structural disadvantage and political marginalisation, there are two major enticements being offered as the 'big ticket' items, if the mine proceeds. The first is that the proponent proposes to upgrade a significant section of the currently unsealed road to dual lane bitumen. This all-weather road upgrade, to enable the transport of the ore on road trains to the export market, will make the road safer in the long term; the trade-off being sharing it with large numbers of road trains (trucks hauling two to three carriages) and

27 In the anthropological literature, the concepts of agency and personhood are understood as deeply intertwined. See, for instance, Wardlow (2006) and Holcombe (2018). 
also making the region more accessible to tourists and other interests. ${ }^{28}$ Another enticement being discussed, and as part of the original local agreement, is the possibility of jobs during construction and operation. As a potentially 20 -year mine, this possibility of employment for local TOs and other Aboriginal people from the region is very significant. This 'opportunity', in particular, is a major element in TOs considering reopening the mine, even though the haulage route has changed-and in a way that is seen to compromise the integrity of both the customary economy and the spiritual values of the land, river and sea countries.

In 2017, the local $A B C$ radio station ran a story about the project and interviewed several senior women from the largest and closest 'affected community'. ${ }^{29}$ According to this report, the women actively opposed reopening the mine for environmental and spiritual reasons. Yet, having since spoken with these same women, I can say that their opposition is a qualified one. If certain elements, including the dust from the transport of the ore can be mitigated and it can be can be guaranteed that certain other environmental changes do not occur, then perhaps jobs for their sons and grandchildren will sway their opposition.

Without having undertaken extensive qualitative research in relation to TOs' and affected community members' hopes, aspirations and concerns about the potential of the mine, some insight can still be drawn from comparable contexts, in both Australia and Canada. ${ }^{30}$ In British Colombia, when First Nations were asked what was needed in order for them to support an industrial-scale liquified natural gas plan, they stated that education, training and employment was the most important issue (Stokes et al. 2019). Likewise, in this NT context, the major challenge will be enabling employment opportunities through the company investing in pre-employment and work-ready programs and ensuring that the workplace facilitates a culturally amenable environment. Workplace retention for Indigenous employees is a major issue in all remote mines (Sarker and Bobongie 2007; Brereton and Parmenter 2008). Although these issues are an element of the SIA for the project, it will be down to the

28 There are other issues as well that are currently unknown, including the length of time it will take to upgrade the road and if and how long the road trains will be using the road before it is sealed. 29 In the interests of maintaining the anonymity of the proponent this $\mathrm{ABC}$ report will remain un-referenced.

30 The extent of fieldwork for my role in the EIS was a five-day trip to communities in the region. 
effective implementation of the agreement as to whether the employment outcomes and other potential social benefits are met (see Everingham et al., Chapter 9, this volume for comparable discussion).

However, the disconnection between the legislation that promotes Aboriginal rights and interests and guide agreement making, and NT Government legislation relating to EIA, does little to facilitate the opportunities that are contained in these agreements. Thus, we find there is very little relationship between the SIA for the development project and the subsequent negotiated agreement.

Likewise, there is no trigger in the SIA process as to the appropriate time to engage with and include the Aboriginal representative body in dialogue about development projects. The role of the regional land council as the mediator and conduit for identifying and protecting Aboriginal interests is not defined other than in the ALRA legislation. There is no consideration of this role in the NT Environment Assessment Act. Rather, the only mention made in the 'Guidelines for the Preparation of Economic and Social Impact Assessment' is to bundle the ALRA and the Native Title Act with the other Commonwealth legislation. Guidance as to what stage to engage Indigenous interests (and the representative body and 'community stakeholder' groups), or the most appropriate mechanisms for engagement, is not provided. To what extent it is the role of the Land Council to inform the TOs of the project prior to the proponent undertaking the SIA is unclear. While the general understanding is that it is the Land Councils' responsibility to inform TOs and affected community groups about the proposed project, at what exact stage this occurs and in what form (i.e. a large community meeting and/or smaller meetings with particular TOs), is not specified in the ToR that proponents receive from the Environmental Protection Authority.

Likewise, the fact that the NT Government often fails to collect royalties from extractive industries, instead encouraging extractive industries to develop infrastructure, appears to be based on the assumption that any infrastructure and development the industry builds will create broader flow-on effects and benefits for communities and the region both during and beyond life-of-mine (see also Everingham et al., Chapter 9, this volume). This ad-hoc opportunistic approach is, again, directed by mainstream external interests with little systematic consideration of longterm Aboriginal interests. 


\section{Unfinished Business: The ALRA and TO Rights and Interests}

When I was initially engaged on the ESIA for this mining project, I was of the understanding that TOs would have veto rights over a key element of it. This key element was in relation to proposed infrastructure on a major river as a transport corridor. My understanding was based on my being engaged, some years previously, as the lead author of the anthropologists' report for the 'Beds and Banks' claim over this river, under the ALRA. The Aboriginal Land Commissioner had recommended the grant of Aboriginal freehold title and, like other people familiar with the claim, especially Aboriginal claimants, I had assumed that it had progressed to the 'finding' (the technical term) of the grant of the river-beds and banks. ${ }^{31}$ However, as I now know, and as I have since informed some of the claimants that I worked with all those years ago (during a field visit for this project), this was not the case. Due to the high degree of 'detriment' (the technical term for opposing interests), the final sign-off by the Commonwealth Minister for Aboriginal Affairs that is required under the ALRA did not occur. This was principally in relation to the opposition of the amateur fishing industry, as was also the case for another 15, mostly beds and banks, claims in the 'Top End' of the NT.

However, coincidently during 2017 and 2018, Minister Scullion, then Federal Minister for Indigenous Affairs, requested the Aboriginal Land Commissioner undertake a review of outstanding Aboriginal land claims (ALC 2019). The ToR for the review indicated that 'a range of political, legal and procedural factors are likely to have contributed to the delayed resolution of detriment issues associated with the ... land claims and therefore warrant consideration in this review. ${ }^{32}$ For over 20 years, these claims had been in limbo and, as such, TOs were not able to exercise their rights as landowners over these customary areas, which also includes the right of veto over development interests (including mining), under the ALRA.

31 The Aboriginal Land Commissioner is a statutory officer of the Commonwealth appointed to perform functions outlined in section 50 of the ALRA. The Commissioner's functions include undertaking inquiries into traditional land claims in the NT.

32 According to media reports, the Federal Minister for Aboriginal Affairs Scullion granted almost $\$ 500,000$ to three industry groups-the NT Seafood Council, the NT Cattlemen's Association and the NT Amateur Fishermen's Association - to help resolve their detriment cases in outstanding land rights claims (Allam 2018; Gibson 2018). See: www.abc.net.au/news/2018-10-31/indigenousadvancement-strategy-funds-given-to-lobby-groups-nt/10451664. 
This was not surprising, and it reflects the disconnection between Commonwealth legislation and NT-based legislation. As the ALRA is Commonwealth legislation, the NT Government had an adversarial approach, consistently opposing land claims during the hearings in pursuing detriment and engaging anthropologists to find inconsistencies in the Aboriginal evidence. This approach to opposing Aboriginal interests was initially driven by the conservative Country Liberal Party who held power in the NT from self-government in 1978 until 2001, when the first Labor Government was elected. It was notable that during the 2002 hearing for the river claim at issue here, the then new Labor Government took an almost facilitative approach to the claim. However, this approach of accommodation has since changed. The 2018 Report on the Review of Detriment outlines the current NT Labor Government's approach. Of particular relevance is the submission made by the Department of Primary Industries and Resources in relation to minerals and energy. As summarised by the Detriment Review Report.

DPIR [Department of Primary Industries and Resources]
claimed detriment on behalf of [4] energy interests in respect of
negotiating agreements with traditional Aboriginal owners and
the uncertainty that a future agreement would be made [i.e. that
veto rights might be exercised]. They also claimed that failure to
reach agreement poses a strong risk that proposed patterns of land
use associated with [extractive] exploration and production could
be adversely affected if access is withdrawn or restricted [i.e. the
land is granted]. (ALC 2019: 181)

The Commissioner was dismissive of the Department of Primary Industries and Resources claim, noting that 'whatever the validity of speculative claims, the ALRA was not intended to accommodate them; much less to permit them to stand in the way of a grant of land to traditional owners' (ALC 2019: 182). Nevertheless, the federal minister still has the final sign-off on the grant of land of all of these claims. As Minister Scullion stated: 'It is critical that this many years into the process we do all we can to help settle outstanding claims to provide certainty and opportunity to all Territorians' (Scullion 2019). ${ }^{33}$ That these other interests have had

33 As the Minister stated in the press release about the report: 'All parties with an interest in the land claims reported on by the Commissioner will be given the opportunity to comment on the report before I make any decision about whether to proceed with the recommendations for grants of land under the Aboriginal Land Rights (Northern Territory) Act 1976 ... I also maintain my commitment to work with all stakeholders to ensure that detriment issues are resolved' (Scullion 2019). It is noteworthy that they also had ample opportunity to comment prior to the report. 
ample opportunity (including government funding), to make their cases of detriment heard, suggests that Aboriginal interests are not compatible with those of 'all [other] Territorians'; and that his focus is ensuring that these 'opportunities' are not curtailed. This response makes clear that the state is more present for some Territorians than others, when it comes to facilitating particular forms of development. It is also of note that Minister Nigel Scullion was, at that time, also an NT Senator. Here the 'state' includes both NT and federal levels.

Unfortunately, the Top End Mining company also submitted a case of detriment to the enquiry, indicating that their business model was threatened by any extension of Aboriginal rights and interests. This was the case, even though it was made clear to them (by myself and the other consultants engaged) that the SIA would also need to include this opposition to the granting of the land as a negative social impact, which could materially compromise their project. Their oppositional approach compounded the need for me to withdraw from further discussions in relation to undertaking additional elements of the SIA (recall that I had attempted to encourage higher standards beyond minimum compliance). ${ }^{34}$

\section{Customary Rights and Interests: Contesting Ecologies of Knowledge}

What are these Aboriginal interests? The detriment review report quoted the original land commissioner's finding for this river claim: 'there are few areas in Australia where the traditional attachment of the Indigenous people to their land exceeds that of the present claim' (ALC 2019: 174). These interests understand the river as sentient, embodying not only customary harvest potential, but also the ancestral travels of the Gilyirringgilyirring (mermaids), and many other totemic species. Sections of the river are associated with the regional Kunapipi ceremonial tradition (Berndt 1951). This necessarily means that those who hold the role Mingirringi (attachment through father's father) and Junggayi (attachment through mother's father) for these places will have to consider a much wider group

34 Likewise, the irony for myself in proceeding in such a role with a company that was opposing the land claim that I had played a major role in preparing was perverse, not to mention professionally and ethically compromising. 
in their decision making. Ultimately, it will be these particular TOs that will carry the decision-making responsibility for river-based aspects of this project and any other development interests.

That TOs do not perceive the human/environment dichotomy that modern Western science and Western society in general practices represents a core challenge to the state, as exemplified by the ESIA process under the EIA. This other set of intangible spiritual interests confounds the state's commitment to extractive capitalism and land as alienable resource empiricism. Such spiritual attachments to land are a direct risk to this enterprise, which may explain why the state practices a local form of 'epistemicide' in this neo-colonial 'global south' (Santos 2014). The marginalising and attempted diminishment of Aboriginal knowledges, as alternative ways of knowing that exist outside of the dominant epistemological norms, presents as an ongoing contest between the valued and undervalued, the recognised and under-recognised, the visible and invisible-even while these Indigenous ethno-epistemologies are increasingly named, and recognised as valid and valued (Maffie 2009). ${ }^{35}$

Yet, as one would also expect, within the regional Aboriginal population there is also contestation over decision-making rights and a diverse range of interests and intersecting responsibilities (see also Trigger 1997). These include those TOs who have specific rights and responsibilities under Aboriginal customary law to maintain and protect particular significant sites. There are also Aboriginal rangers, as the region just to the north of the major community at hand was recently declared an Indigenous Protection Area and the local land and sea rangers work out of this community. These rangers work with modern Western science and their ethnoecological knowledges, and they bring their $\mathrm{TO}$ rights and responsibilities to their work. The third loose grouping are those who are interested in the potential work that will come from the mining construction and operation, and the local Aboriginal Development Corporation is very interested in encouraging these. All of these interests-which are not mutually exclusive: individuals can endorse several positions-have to be weighed in the final decision by the TOs. Noting that, as I write, the extent of their legal decision-making rights in relation to the river is still unfolding.

35 As seen, for instance, in the growing body of research on ethnobotany (Janke 2009; Robinson 2010; Ens 2012; Ens et al. 2012) and the expansion of the Indigenous Protected Area program, which jointly recognises the cultural and ecological values of the landscape (Hill et al. 2012). 


\section{The State and Negotiated Mining Agreements}

The local agreements that Top End Mining took over incorporate a range of benefits that will be in the TOs' minds when they meet to discuss the project, post the EIA finalisation. These agreements, which were effectively abandoned along with the previous mine, were picked up by Top End Mining. Of note, at a regional full council meeting of the NLC, then CEO Joe Morrison stated that global market forces had played a part in the mine's demise and had made the community 'realise that we've just got to be a bit more aware of commodity prices and the impact that it has on local economies'. This issue is exacerbated with junior companies who are more likely to seek to develop smaller, and thus riskier, deposits.

As O'Faircheallaigh indicates, land use agreements can offer Aboriginal groups a degree of autonomy from the state in their provision of access to mining income and other benefits (O'Faircheallaigh 2010). The state does not play any role in these agreements: they are between the Indigenous representative body, on behalf of TOs, and the company. However, this raises questions as to whether there should be some sort of public policy framework to guide their negotiation and implementation. These questions have been explored in the Canadian First Nations context. In the Northwest Territories of Canada it was found that the roles of mining companies, Aboriginal organisations and government are not properly defined and some inappropriate off-loading of responsibilities by government is occurring' (Kennett, quoted in Cameron and Leviton 2014: 29).

In the NT, this notable absence of the state from any role in agreement making is a reflection of their broader absence in not establishing public policy and institutional reform to address the raft of land rights that Aboriginal people have been successful in achieving. The ALRA and the Native Title Act seem to operate in a parallel, and still contested, sphere alongside NT Government legislation and programs as a form of segmentary state logic. It is entirely up to the capability of the Indigenous representative body to ensure that the agreement encompasses all that is sought by their constituents, including forms of community development. As it is standard for agreements to be commercial-in-confidence, the possible relationships between state-based social programs and the social programs offered within the agreements are not drawn. This includes 
features such as education and training opportunities offered by the mining company through the agreement, and those that may already exist as public programs within the community. The capacity of a mining junior to deliver on these commitments, or the Land Council to ensure they are implemented, is not tested by the state.

Likewise, there is also the risk that the NT Government will cut its expenditure on communities in receipt of royalties and other benefits under agreements, negating some of their positive impact (O'Faircheallaigh 2004, 2010). This 'substitution funding', where citizenship entitlements-such as health, housing and education-are effectively privatised, has been found to be the case in mining regions such as the Pilbara (Holcombe 2009; Taylor 2018). Likewise, in the NT, even before there were comprehensive agreements that included education and training and other negotiated community benefits, Jon Altman records early cases from the 1980s and 1990s where substitution funding was standard for outstation services in the region serviced by the Gagadju Association that was established from the Ranger uranium mine (Altman 1998 in O'Faircheallaigh 2004). In light of the precedence of substitution funding elsewhere in the NT and remote WA, the presence of the company is likely to further facilitate the absence of the state in terms of infrastructure and other public services in this region.

\section{Conclusions}

This discussion of a junior mining company in northern Australia has been nested within the broader political economy of the ongoing marginalisation of Aboriginal rights and interests. While the Aboriginal citizens of the NT have consistently won court battles in relation to their land, those victories have not translated into public policy and institutional reform to ensure that development is inclusive of the majority permanent population of these lands (Morrison 2017: 4). Likewise, though the land use agreements that are routinely negotiated between Aboriginal interests and developers encompass a range of mechanisms that address disadvantage, public policy has not been developed to guide their negotiation, terms of reference or implementation. This absence of the state is also mirrored in the mainstream EIA processes that have been transplanted to these remote Aboriginal domains. Even though Aboriginal interests are the major landholding group, they are treated as another set of stakeholders. 
For the junior miner discussed in this chapter, the EIA processes function as a default corporate social performance system, and the inadequacy of the EIA process highlights this significant gap in the operations of junior companies more generally (although any mining company in this context is also likely to pursue a compliance-based approach). The SIA elements of the EIA regulatory framework, though a lesser standard than other states, reflect a conventional SIA approach that seeks to 'do no harm', focusing on mitigating negative impacts. Such an approach is not appropriate in contexts where the majority interests are Aboriginal, as it not only misses opportunities to contribute to genuine collaboration with these interests, but they also emerge from the presumption that these interests are aligned with the dominant mainstream population and nested among the other stakeholder groups.

The possibility of an extractive-led pathway to Aboriginal development, levering off the local agreement, is a hopeful one. The targeted support for big project development, such as mining, however still functions on the theory of trickle-down economics. As Peter Yu stated, this won't work because it is not accompanied by a range of structural reforms to support Indigenous economic inclusion (Yu quoted in Morrison 2017: 3). That the operations of this junior miner fit into this neocolonial paradigm was notably apparent in their adversarial approach to the granting of the beds and banks land claim, as potentially impacting their operation by granting TOs free prior informed consent rights. Such an approach has Indigenous people as obstacles to development, rather than development partners.

This example from the NT has revealed a selectively absent state. Although my focus has been on absence in the context of extractive capitalism, in the broader socioeconomic context within which Aboriginal citizens live, the state looms ever present in forms of punitive governance and surveillance in a coupling of responsibilities and duties with citizenship entitlements. On the other hand, there has been a notable retreat of social welfare, such as the Community Development Employment Program and a mainstreaming of Indigenous services, such as housing. The state is notably absent in relation to the intersection of Indigenous interests and development interests, as market forces are enabled to be directive in shaping social outcomes in the interests of growth in state revenue. In the NT, the state has never been present in relation to the many negotiated mining land use agreements between its Aboriginal citizens and mining companies. In this context of development, while it may appear that these Aboriginal interests are appropriately served by Land Councils and 
specific legislation such as the ALRA, without intersecting and supportive state legislation the contest between Indigenous and non-Indigenous interests continues.

Ironically, this absent state is also reflected as a form of fiscal absence: in the absence of claiming taxes from the industry, at both territory and federal levels. This approach assumes that any infrastructure and development the industry builds will have flow-on and broader benefits to communities and the region both during and beyond life-of-mine. Yet, market-based solutions to social problems, as reflective of less state, is a failure of the state to meet its obligations and commitments to its most vulnerable citizens.

\section{References}

AFG (Australian Federal Government), 2015. Our North, Our Future: White Paper on Developing Northern Australia. Canberra: Commonwealth of Australia.

AIATSIS (Australian Institute of Aboriginal and Torres Strait Islander Studies), 2016. 'Native Title Information Handbook: Northern Territory.' Canberra: AIATSIS.

ALC (Aboriginal Land Commissioner), 2019. Report on Review of Detriment: Aboriginal Land Claims Recommended for Grant But Not Yet Finalised. Canberra: Office of the ALC.

Allam, L., 2018. 'Indigenous Groups Call for Investigation into Scullion Fund Stoush.' The Guardian, 3 November.

Altman, J. and M. Hinkson (eds), 2007. Coercive Reconciliation: Stabilise, Normalise, Exit Aboriginal Australia. Melbourne: Arena Publications.

Altman, J. and S. Kerins (eds), 2012. People on Country: Vital Landscapes, Indigenous Futures. Melbourne: Federation Press.

Altman, J.C., C. Linkhorn and J. Clarke, 2005. 'Land Rights and Development Reform in Remote Australia.' Canberra: The Australian National University, Centre for Aboriginal Economic Policy Research (Discussion Paper 276).

Altman, J. and D. Martin (eds), 2009. Power, Culture, Economy: Indigenous Australians and Mining. Canberra: ANU E Press (Centre for Aboriginal Economic Policy Research Monograph 30). doi.org/10.22459/CAEPR30. 08.2009 
AMEC (Association of Mining and Exploration Companies), 2019. Annual Report. Viewed 20 October 2020 at: secureservercdn.net/198.71.233.51/ 0h5.0cf.myftpupload.com/wp-content/uploads/2020/03/AMEC-2019Annual-Report.pdf

Anon., 2019. 'What Criteria Classify a Company as a Junior Gold Miner?' Investopedia blog, 25 June. Viewed 28 September 2020 at: www.investo pedia.com/ask/answers/040815/what-criteria-classify-company-junior-goldminer.asp

Anon., n.d.a. 'Mineral Resource Stocks-Junior vs. Senior Mining Companies.' UndervaluedEquity blog. Viewed 28 September 2020 at: undervaluedequity. $\mathrm{com} /$ mineral-resource-stocks-junior-vs-senior-mining-companies/

Anon, n.d.b. 'Why Mexico is the Go-To Place.' Junior Miners blog. Viewed 28 September 2020 at: www.juniorminers.com/news/mining-explorationmexico.html

Archer, R., J. Russell-Smith, S. Kerins, B. Costanza, A. Edwards and K. Sangha, 2019. 'Change and Continuity: The North Australian Cultural Landscape.' In J. Russell-Smith, G. James, H. Pedersen and K.K. Sangha (eds), Sustainable Land Sector Development in Northern Australia: Indigenous Rights, Aspirations, and Cultural Responsibilities. Boca Raton (FL): CRC Press. doi.org/10.1201/ 9780429471056

Bainton, N., 2020. 'Mining and Indigenous Peoples.' In Oxford Research Encyclopedia of Anthropology. Oxford: Oxford University Press. doi.org/ 10.1093/acrefore/9780190854584.013.121

Bebbington, A. and D. Humphreys Bebbington, 2018. 'Mining, Movements and Sustainable Development: Concepts for a Framework.' Sustainable Development 26: 441-449. doi.org/10.1002/sd.1888

Berndt, R., 1951. Kunapipi: A Study of an Australian Aboriginal Religious Cult. Melbourne: Cheshire.

Boiral, O., 2013. 'Sustainability Reports as Simulacra? A Counter-account of A and A+ GRI Reports.' Accounting, Auditing and Accountability Journal 26: 1036-1071. doi.org/10.1108/aaaj-04-2012-00998

Brereton, D. and J. Parmenter, 2008. 'Indigenous Employment in the Australian Mining Industry.' Journal of Energy \& Natural Resources Law 26: 66-78. doi.org/10.1080/02646811.2008.11435178

Cameron, E. and T. Levitan, 2014. 'Impact and Benefit Agreements and the Neoliberalization of Resource Governance and Indigenous-State Relations in Northern Canada.' Studies in Political Economy 93: 25-52. 
Campbell, R., J. Linqvist, B. Browne, T. Swann and M. Grudnoff, 2017. 'Dark Side of the Boom: What We Do and Don't Know about Mines, Closures and Rehabilitation.' Canberra: The Australia Institute.

Canavan, M. and N. Scullion, 2017. 'First Nations Peoples Critical to Developing Northern Australia.' Media release, 11 December. Viewed 28 September 2020 at: www.minister.industry.gov.au/ministers/canavan/media-releases/firstnations-peoples-critical-developing-northern-australia

Chambers, I., J. Russell-Smith, R. Costanza, J. Cribb, S. Kerins, M. George and G. James, 2018. 'Australia's North, Australia's Future: A Vision and Strategies for Sustainable Economic, Ecological and Social Prosperity in Northern Australia.' Asia Pacific Policy Studies 5: 615-640. doi.org/10.1002/app5.259

Chlanda, E., 2017. 'Fracking Interim Report: Two Bob Each Way?' Alice Springs News, 17 July.

Cox, L., 2018. “"Not Safe, Not Wanted”: Is the end of NT Fracking ban a taste of things to come?' The Guardian, 18 June.

D’Abbs, P., 2017. 'Alcohol Policy in the Northern Territory: Toward a Critique and Refocusing.' Submission to the Northern Territory Alcohol Policies and Legislation Review.

Davidson, H., 2018. ‘ $\$ 500 \mathrm{~m}$ Meant for Indigenous Services was Spent Elsewhere by NT Government.' The Guardian, 11 January.

Davidson, P., P. Saunders, B. Bradbury and M. Wong, 2018. 'Poverty in Australia, 2018.' Sydney: Australian Council of Social Services and University of New South Wales, Poverty and Inequality Partnership (Report 2).

Dougherty, M., 2011. 'The Global Mining Industry, Junior Firms and Civil Society Resistance in Guatemala. Bulletin of Latin American Research. Society for Latin American Studies.

Dougherty, M.L., 2013. 'The Global Gold Mining Industry: Materiality, RentSeeking, Junior Firms and Canadian Corporate Citizenship.' Competition and Change 17: 339-354. doi.org/10.1179/1024529413z.00000000042

Doyle, C. and J. Cariño, 2013. Making Free, Prior \& Informed Consent a Reality: Indigenous Peoples and the Extractives Sector. London: Philippine Indigenous Peoples Links.

Ens, E., 2012. 'Conducting Two-Way Ecological Research.' In J. Altman and S. Kerins (eds), People on Country: Vital Landscapes, Indigenous Futures. Melbourne: Federation Press. 
Ens, E., M. Finlayson, K. Preuss, S. Jackson and S. Holcombe, 2012. 'Australian Approaches for Managing "Country” Using Indigenous and Non-Indigenous Knowledge.' Journal of Ecological Management and Restoration 13: 100-107. doi.org/10.1111/j.1442-8903.2011.00634.x

Escobar, A. 2008. Territories of Difference: Place, Movement, Life, Redes. Durham (NC): Duke University Press.

Feit, H., 2010. 'Neoliberal Governance and James Bay Cree Governance: Negotiated Agreements, Oppositional Struggles, and Co-Governance.' In M. Blaser, R. de Costa, D. McGregor and W.D. Coleman (eds), Indigenous Peoples and Autonomy. Vancouver: University of British Columbia Press.

Fonseca, A., 2010. 'How Credible are Mining Corporations' Sustainability Reports? A Critical Analysis of External Assurance under the Requirements of the International Council on Mining and Metals.' Corporate Social Responsibility and Environmental Management 17: 355-370. doi.org/10.1002/csr.230

Gibson, J., 2018. 'Indigenous Advancement Funds Given to Lobby Groups Impacted by Aboriginal Land Claims.' Australian Broadcasting Corporation, 31 October. Viewed 28 September 2020 at: www.abc.net.au/news/201810-31/indigenous-advancement-strategy-funds-given-to-lobby-groups-nt/ 10451664

Gibson, P., 2015. 'Removed for Being Aboriginal: Is the NT Creating Another Stolen Generation?' The Guardian, 4 March.

Götzman, N. and N. Bainton, 2019. 'Papua LNG Human Rights Impact Assessment: Focus on Gender, Security and Conflict.' Copenhagen: Danish Institute for Human Rights.

Hill, R., C. Grant, M. George, C. Robinson, S. Jackson and N. Abel, 2012. 'A Typology of Indigenous Engagement in Australian Environmental Management: Implications for Knowledge Integration and Social Ecological System Sustainability.' Ecology and Society 17: 23. doi.org/10.5751/es-04587170123

Hill, R., E.K. Harding, D. Edwards, J. O'Dempsey, D. Hill, A. Martin and S. McIntryre-Tamwoy, 2008. A Cultural and Conservation Economy for Northern Australia: A Proof-of-Concept Study. Canberra: Land and Water Australia.

Hindess, B., 2002. 'Neoliberal Citizenship.' Citizenship Studies 6: 127-143.

Hodge, A.R., 2018. 'Towards Contribution Analysis.' In T. Addison and A.R. Roe (eds), Extractive Industries: The Management of Resources as a Driver of Sustainable Development. Oxford: Oxford University Press. 
Holcombe, S., 2009. 'Indigenous Entrepreneurialism and Mining Land Use Agreements.' In J. Altman and D. Martin (eds), Power, Culture and Economy: Indigenous Australian and Mining. Canberra: ANU E Press (Centre for Aboriginal Economic Policy Research Monograph 30). doi.org/10.22459/ caepr30.08.2009.07

, 2018. Remote Freedoms: Politics, Personhood and Human Rights in Aboriginal Central Australia. Stanford (CA): Stanford University Press. doi.org/ $10.1515 / 9781503606487$

Janke, T., 2009. 'Indigenous Ecological Knowledge and Natural Resources in the Northern Territory: Report on the Current Status of Indigenous Intellectual Property.' Darwin: Northern Territory Natural Resource Management Board.

Johnston, S. and D. Kemp, 2019. 'Organising for Social Performance in the Global Mining Industry: A Snapshot Study.' St Lucia: University of Queensland, Centre for Social Responsibility in Mining.

Kemp. D. and J.R. Owen, 2013. 'Community Relations and Mining: Core to Business, But Not “Core Business".' Resources Policy 38: 523-531. doi.org/ 10.1016/j.resourpol.2013.08.003

Kemp, D. and F. Vanclay, 2013. 'Human Rights and Impact Assessment: Clarifying the Connections in Practice.' Impact Assessment and Project Appraisal 31: 86-96. doi.org/10.1080/14615517.2013.782978

Kral, I., 2017. 'Submission to the Inquiry into the Appropriateness and Effectiveness of the Objectives, Design, Implementation and Evaluation of the Community Development Program (CDP).' Canberra: Parliament of Australia.

Langton, M., 2013. The Quiet Revolution: Indigenous People and the Resources Boom. Sydney: Harper Collins (The Boyer Lectures 2012).

, 2017. 'Australian Mining Industry Annual Lecture.' Viewed 28 September 2020 at: files.ozblogistan.com.au/sites/4/2017/06/11132429/LANGTON_ 2017_MINING_INDUSTRY_LECTURE.pdf

Langton, M. and O. Mazel, 2008. 'Poverty in the Midst of Plenty: Aboriginal People, the "Resource Curse" and Australia's Mining Boom.' Journal of Energy \& Natural Resources Law 26: 31-65. doi.org/10.1080/02646811.2008.1143 5177

Langton, M., O. Mazel, L. Palmer, K. Shain and M. Teehan (eds), 2003. Settling with Indigenous Peoples: Modern Treaty and Agreement Making. Melbourne: Federation Press. 
Lea, T., K. Howey and J. O’Brian, 2018. 'Waging Paper Warfare: Subverting the Damage of Extractive Capitalism in Kakadu.' Oceania 88: 305-319. doi.org/ 10.1002/ocea.5203

Lyons, M., J. Bartlett and P. McDonald, 2016. 'Corporate Social Responsibility in Junior and Mid-Tier Resources Companies Operating in Developing Nations: Beyond the Public Relations Offensive. Resources Policy 50: 204-213. doi.org/ 10.1016/j.resourpol.2016.10.005

Mackie, K. and D. Meacheam, 2016. 'Working on Country: A Case Study of Unusual Environmental Program Success.' Australasian Journal of Environmental Management 23: 157-174. doi.org/10.1080/14486563.2015.1094752

MacNaughton, G. and P. Hunt, 2011. 'A Human Rights Based Approach to Social Impact Assessment.' In F. Vanclay and A.M. Esteves (eds), New Directions in Social Impact Assessment: Conceptual and Methodological Advances. Cheltenham: Edward Elgar. doi.org/10.4337/9781781001196.00034

Maffie, J., 2009. "'In the End, We have the Gatling Gun, and They Do Not": Future Prospects of Indigenous knowledges.' Futures 41: 53-65. doi.org/ 10.1016/j.futures.2008.07.008

Martin, D.F., F. Morphy, W.G. Sanders and J. Taylor, 2002. Making Sense of the Census: Observations of the 2001 Enumeration in Remote Aboriginal Australia. Canberra: ANU E Press (Centre for Aboriginal Economic Policy Research Monograph 22). doi.org/10.22459/caepr22.03.2004

McGrath, P.F. (ed.), 2016. The Right to Protect Sites: Indigenous Heritage Management in the Era of Native Title. Canberra: AIATSIS Research Publications.

Morrison, J., 2017. 'Keynote Address.' Presentation to the Northern Australian Development Conference, Cairns, 19 June.

NSWSG (New South Wales State Government), 2017. 'Social Impact Assessment Guideline.' Sydney: Department of Planning and Environment.

NTG (Northern Territory Government), 2013. 'Guidelines for the Preparation of an Economic and Social Impact Assessment.' Darwin: Environmental Protection Authority.

- 2018a. Final Report of the Scientific Enquiry into Hydraulic Fracking in the NT. Darwin: NTG.

, 2018b. 'Northern Territory Correctional Services Annual Statistics: 2016-2017.' Darwin: Criminal Justice Research and Statistics Unit. 
, 2020. 'Northern Territory Economy.' Darwin: Department of Treasury and Finance.

O'Faircheallaigh, C., 2004. 'Denying Citizens their Rights? Indigenous People, Mining Payments and Service Provision.' Australian Journal of Public Administration 63(2): 42-50. doi.org/10.1111/j.1467-8500.2004.00377.x

, 2010. 'Aboriginal-Mining Company Contractual Agreements in Australia and Canada: Implications for Political Autonomy and Community Development.' Canadian Journal of Development Studies 30: 69-86. doi.org/ 10.1080/02255189.2010.9669282

2011. 'Social Impact Assessment and Indigenous Social Development.' In F. Vanclay and A.M. Esteves (eds), New Directions in Social Impact Assessment: Conceptual and Methodological Advances. Cheltenham: Edward Elgar. doi.org/ $10.4337 / 9781781001196.00020$

Outsider Club, n.d. 'About Us.' Viewed 16 October 2020 at: www.outsiderclub. com/about

Peck, J., 2013. 'Polanyi in the Pilbara.' Australian Geographer 44: 243-264. doi.org/ 10.1080/00049182.2013.817037

Peel, M., R. Campbell and R. Dennis, 2014. 'Mining the Age of Entitlement: State Government Assistance to the Minerals and Fossil Fuel Sector.' Canberra: Australia Institute (Technical Brief 31).

Pilkington, J., 2009. Aboriginal Communities and the Police's Taskforce Themis: Case Studies in Remote Aboriginal Community Policing in the Northern Territory. Darwin: North Australian Aboriginal Justice Agency.

Pyne, A., 2012. 'Ten Proposals to Reduce the Over-Imprisonment of Aboriginal Men in NT Prisons.' Australian Indigenous Law Review 16(2): 2-17.

QSG (Queensland State Government), 2018. 'Social Impact Assessment Guideline.' Brisbane: Department of State Development, Manufacturing, Infrastructure and Planning.

Robinson, D.F., 2010. 'Traditional Knowledge and Biological Product Derivative Patents: Benefit Sharing and Patent Issues relating to Camu Camu, Kakadu Plum and Açaí Plant Extracts.' Tokyo: United Nations University, Institute of Advanced Studies (Traditional Knowledge Bulletin).

Roche, C. and S. Judd, 2016. 'Ground Truths: Taking Responsibility for Australia’s Mining Legacies.' Sydney: Mineral Policy Institute. 
Ruggie J., 2008. Report of the Special Representative of the Secretary-General on the Issue of Human Rights and Transnational Corporations and Other Business Enterprises.' New York: United Nations General Assembly, Human Rights Council. doi.org/10.1163/2210-7975_hrd-4208-0204

- 2011. Guiding Principles on Business and Human Rights: Implementing the United Nations Respect, Protect and Remedy Framework. United Nations Human Rights Office, Human Rights Commission.

Sanders, W., 2017. 'Submission to the Inquiry into the Appropriateness and Effectiveness of the Objectives, Design, Implementation and Evaluation of the Community Development Program (CDP).' Canberra: Parliament of Australia.

Santos, B.S., 2014. Epistemologies of the South: Justice Against Epistemicide. Boulder (CO): Paradigm Press.

Sarker, T. and G. Bobongie, 2007. 'Survey of Aboriginal Former Employees and Trainees of Argyle Diamond Mine.' St Lucia: University of Queensland, Centre for Social Responsibility in Mining.

Scullion, N., 2019. 'Statement on the Aboriginal Land Commissioner's Report on Review of Detriment.' Media release, 21 February. Viewed 28 September 2020 at: www.indigenous.gov.au/news-and-media/announcements/ministerscullion-statement-aboriginal-land-commissioner\%E2\%80\%99s-report

Slowey, G., 2008. Navigating Neoliberalism: Self Determination and the Mikisew Cree First Nation. Vancouver: University of British Columbia Press.

Spiers Williams, M., 2019. 'Innervating Colonialism: Exploring the Retraction of Indigenous Rights through Two Sentencing Provisions.' Australian Feminist Law Journal 44: 203-220. doi.org/10.1080/13200968.2018.1547102

Stokes, D., B.G. Marshall and M.M. Veiga, 2019. 'Indigenous Participation in Resource Developments: Is it a Choice?' Extractive Industries and Society 6: 50-57. doi.org/10.1016/j.exis.2018.10.015

Sullivan, P., 2011. Belonging Together: The Politics of Disenchantment in Australian Indigenous Policy. Canberra: Aboriginal Studies Press.

Taylor, J., 2018. 'Change in Aboriginal Social Indicators in the Pilbara: 20012016.' Report to the Pilbara Regional Implementation Committee.

Taylor, J., J. Bern and K. Senior, 2000. Ngukurr at the Millennium: A Baseline Profile for Social Impact Planning in South-East Arnhem Land. Canberra: The Australian National University, Centre for Aboriginal Economic Policy Research (Monograph 18). 
Taylor. J. and B. Scambary, 2005. Indigenous People and the Pilbara Mining Boom: A Baseline for Regional Participation. Canberra: ANU E Press (Centre for Aboriginal Economic Policy Research Monograph 25). doi.org/10.22459/ IPPMB.01.2006

Trigger, D., 1997. 'Century Mine: Preliminary Thoughts on the Politics of Indigenous Responses.' In D. Smith and J. Finlayson (eds), Fighting Over Country: Anthropological Perspectives. Canberra: The Australian National University, Centre for Aboriginal Economic Policy Research (Monograph 12).

Turnbull, M., 2017. 'Investing in the Future Strength of the Australian Resources Sector.' Press release, 2 September. Viewed 22 September 2020 at: www.minister.industry.gov.au/ministers/joyce/media-releases/investingfuture-strength-australian-resources-sector

Walsh, C., 2018. 'Northern Territory Government in Financial Crisis, Will Seek Bailout from Canberra.' Australian Broadcasting Corporation, 14 December. Viewed 28 September 2020 at: www.abc.net.au/news/2018-12-14/ntgovernment-financial-report-commonwealth-bailout/10621136

Wardlow, H., 2006. Wayward Women: Sexuality and Agency in a New Guinea Society. Berkeley: University of California Press. doi.org/10.1111/j.15481352.2010.01116.x

WASG (Western Australia State Government), 2020. 'Western Australia Economic Profile, August 2020.' Perth: Department of Jobs, Science, Tourism and Innovation.

World Bank, 2014. Voice and Agency: Empowering Women and Girls for Shared Prosperity. Washington (DC): World Bank.

Zillman, S., 2018. 'Why is the Northern Territory in So Much Debt?' Australian Broadcasting Corporation, 19 December. Viewed 28 September 2020 at: www.abc.net.au/news/2018-12-19/why-is-the-northern-territory-in-so-muchdebt/10632654 
This text is taken from The Absent Presence of the State in LargeScale Resource Extraction Projects, edited by Nicholas Bainton and Emilia E. Skrzypek, published 2021 by ANU Press, The Australian National University, Canberra, Australia. 